\title{
Instrumen Kecerdasan Moral untuk Anak: Validitas dan Reliabilitas
}

\author{
Yuli Kurniawati Sugiyo Pranoto ${ }^{\circledR}{ }^{\bowtie}$, Falakhul Auliya ${ }^{2}$, Uci Saputri ${ }^{1}$ \\ Pendidikan Guru Pendidikan Anak Usia Dini, Universitas Negeri Semarang, Indonesia ${ }^{1}$ \\ Pendidikan Islam Anak Usia Dini, Institut Agama Islam Negeri Salatiga, Indonesia ${ }^{2}$ \\ DOI: $10.31004 /$ obsesi.v6i3.1803
}

\begin{abstract}
Abstrak
Uji validitas dan reliabilitas terhadap instrumen kecerdasan moral dengan 3 domain moral perlu dilakukan. Sampel pada penelitian ini berjumlah 208 anak usia dini, berasal dari 13 Taman Kanak-kanak di Kota Semarang. Dimensi kecerdasan moral mengacu pada teori Borba yaitu empati, hati nurani, pengendalian diri, rasa hormat, kebaikan, toleransi, dan keadilan. Empat belas item dengan 3 pertanyaan (apa yang dipikirkan, dirasakan, dan dilakukan anak) disiapkan, direvisi, dan diedit untuk diberikan kepada para ahli. Analisis item dihitung menggunakan teknik korelasi product moment dan teknik corrected item total correlation. Hasil penelitian adalah: (a) analisis dengan teknik korelasi product moment menunjukkan semua item pada skala kecerdasan moral berkorelasi dengan skor tes secara keseluruhan; (b) analisis dengan teknik corrected item total correlation menunjukkan semua item pada skala kecerdasan moral memiliki $\mathrm{r}$ hitung > $\mathrm{r}$ tabel; (c) nilai alpha cronbach skala kecerdasan moral sebesar 0,75. Berdasarkan hasil analisis maka instrumen kecerdasan moral telah layak digunakan.
\end{abstract}

Kata Kunci: kecerdasan moral, validitas dan reliabilitas, pengembangan tes

\begin{abstract}
Referring to Borba's moral dimensions, this study highlighted intelligence by considering the aspects of empathy, conscience, self-control, respect, kindness, tolerance, and justice. The study involved 208 early childhood education students from 13 kindergartens in Semarang City. The instrument, which had been validated by experts, consisted of 14 items with respectively three questions regarding children's thoughts, feelings, and actions. The product-moment correlation and corrected item-total correlation were deployed to analyze the responses. The study highlighted the following findings: (a) based on the product-moment correlation, all items regarding the moral intelligence scale correlated with the overall test scores, (b) based on the corrected item-total correlation, all items regarding the moral intelligence scale resulted in $r$ count $>r$ table, $(c)$ the value of the Cronbach's alpha on the moral intelligence scale was 0.75 . The study came up with a conclusion that the instrument of moral intelligence is appropriate for a further implementation.
\end{abstract}

Keywords: moral intelligence, validity and reliability, test development

Copyright (c) 2021 Yuli Kurniawati Sugiyo Pranoto, et al.

$\square$ Corresponding author:

Email Address : yuli.kurniawati.sp@mail.unnes.ac.id (Semarang, Indonesia)

Received 13 May, Accepted 19 October 2021, Published 27 October 2021 


\section{PENDAHULUAN}

Moral merupakan salah satu kecerdasan terpenting dan memiliki pengaruh besar dalam kehidupan manusia (Ibrahim \& Al-mehsin, 2016);(Naqashzadeh \& Sabahizadeh, 2016); (Oktaviana \& Wuryandani, 2019). Kecerdasan moral anak prasekolah sangat penting untuk dipahami dan dipelajari lebih dalam sehingga dapat dijadikan sebagai masukan dalam mengembangkan kecerdasan moral sejak dini (Pranoto, 2017). Pentingnya pemahaman kecerdasan moral pada anak usia dini juga telah banyak disampaikan oleh para ahli seperti Piaget, Kohlberg, dan Vygotsky. Para ahli berpendapat bahwa moral anak berkembang selama usia sekolah (Al-Somadi, 2012). Namun, para ahli tersebut menekankan pada perkembangan kecerdasan moral hanya pada aspek kognitif pengetahuan moral.

Pengetahuan moral sangat penting bagi perkembangan anak, akan tetapi perkembangan kecerdasan moral hendaknya tidak hanya sebatas pengetahuan moral. Beberapa ahli baru seperti Borba, Coles, Lickona, dan Santrock mengkritik teori moral yang telah dikembangkan oleh para ahli sebelumnya. Mereka berpendapat bahwa perkembangan kecerdasan moral mencakup tiga domain moral, yaitu pengetahuan moral, perasaan moral, dan tindakan moral (Borba, 2001);(Coles, 2005); (Santrock, 2007); (Prasetiawan \& Barida, 2018). Perasaan moral yang menjadi sumber energi manusia untuk bertindak sesuai dengan nilainilai kebenaran juga perlu dikembangkan. Sedangkan perilaku moral merupakan keluaran dari pengetahuan dan perasaan moral (Hudi, 2017). Perkembangan ketiga ranah moral ini menunjukkan bahwa kecerdasan moral anak berkembang (Sit, 2010).

Kecerdasan moral menggambarkan kemampuan seseorang untuk mengamalkan dasar-dasar etika pada tujuan, nilai, dan perilaku individu dalam kehidupan (Bozaci, 2014); (Saleh, 2018). Jika manusia tidak memiliki kecerdasan moral, maka ia tidak akan memperdulikan orang lain, walaupun memiliki kecerdasan verbal dan logis yang tinggi (Altan, 2017). Mewujudkan kecerdasan moral, kemudian kecerdasan moral sejak usia dini.

Pengembangan kecerdasan moral pada anak usia dini akan memandu anak untuk memiliki interaksi sosial yang positif dan sehat (Bozaci, 2014); (Retnowati, Salim, \& Saleh, 2018). Hal tersebut menunjukkan bahwa perkembangan moral seseorang sangat erat kaitannya dengan lingkungan sosialnya, sehingga Kohlberg menekankan bahwa pengembangan moralitas manusia dilakukan secara bertahap (Zhang \& Zhao, 2017). Secara bertahap anak akan meningkatkan kecerdasan moralnya melalui model perilaku moral yang ditiru, serta memberikan penguatan dari lingkungan sosialnya (Ahyani \& Dhini, 2011).

Kecerdasan moral anak usia dini dapat dikembangkan, diamati, dan diukur. Namun selama ini pengukuran kecerdasan moral anak usia dini cenderung melibatkan pihak kedua seperti orang tua dan guru. Seperti penelitian yang dilakukan oleh (Rafika, Risma, \& Febrialismanto, 2018); (Ahsan, Dian, Adisantika, \& Ayu, 2014) yang menggunakan metode observasi dengan bantuan orang dewasa untuk mengukur kecerdasan moral anak usia dini. Sehingga pengembangan skala kecerdasan moral ini melibatkan partisipasi langsung anak usia dini untuk mengungkapkan pendapat anak secara langsung. Penelitian ini melibatkan anak secara langsung mengingat anak-anak dapat memberikan informasi yang akurat dan berharga (O'Reilly \& Dogra, 2018). Selain itu, pengukuran kecerdasan moral pada penelitian sebelumnya hanya diukur dari satu domain. Seperti penelitian yang dilakukan oleh (Kosasih \& Rahmaniah, 2014). Penelitian ini melibatkan peran guru dalam menilai perilaku moral anak. Selain itu penelitian yang dilakukan oleh (Rosyida \& Endang, 2016) juga melibatkan peran peneliti dalam menilai perilaku moral anak. Oleh karena itu, instrumen kecerdasan moral ini tidak hanya mengukur satu domain moral saja, namun mengukur tiga domain moral yaitu pengetahuan moral (moral knowing), perasaan moral (moral feeling), dan perilaku moral (moral action).

Perkembangan skala kecerdasan moral mengacu pada teori (Borba, 2001; (Auliya, Pranoto, Sunawan, \& Sunarso, 2021)) yang menyatakan bahwa terdapat 7 kebajikan moral. Kebajikan moral ini termasuk empati, hati nurani, kebaikan, pengendalian diri, rasa hormat, toleransi, dan keadilan. Ketujuh kebajikan tersebut disajikan dalam bentuk ilustrasi cerpen. 
Beberapa penelitian telah menggunakan aspek kecerdasan moral yang dikembangkan oleh (Borba, 2001) sebagai indikator untuk mengukur kecerdasan moral pada anak usia dini. Seperti penelitian yang dilakukan oleh (Raihana \& Wiwik, 2016) mengenai status ibu dan pengaruhnya terhadap kecerdasan moral anak prasekolah. Selain itu, penelitian yang dilakukan (Septiani \& Itto, 2017) juga mengembangkan skala kecerdasan moral untuk mengukur keterlibatan ayah dalam pola asuh kecerdasan moral anak. Namun demikian, masih belum ada kajian kritis terhadap validitas dan reliabilitas instrumen kecerdasan moral. Peneliti biasanya tertarik untuk mengetahui validitas dan reliabilitas instrumen dalam sebuah proyek penelitian untuk mengetahui apakah instrumen yang akan digunakan akurat dan stabil untuk mengukur variabel yang akan diteliti.

Penelitian ini bertujuan untuk menganalisis validitas dan reliabilitas skala kecerdasan moral yang telah dikembangkan. Temuan penelitian ini akan berkontribusi pada pengukuran kecerdasan moral yang melibatkan partisipasi anak secara langsung

\section{METODOLOGI}

Dua ratus delapan anak usia 5-6 tahun (106 laki-laki dan 102 perempuan) dilibatkan dalam penelitian ini secara langsung. Anak tersebut berasal dari 13 Taman Kanak-kanak di Kota Semarang. Mereka terlibat secara sukarela dalam penelitian ini dan telah mendapatkan izin dari orang tua dan sekolah.

Pengukuran kecerdasan moral anak usia dini dalam penelitian ini menggunakan Skala Kecerdasan Moral. Langkah-langkah penyusunan skala Kecerdasan Moral adalah sebagai berikut (Khampa, 2019): 1) Sebelum menyusun skala, peneliti merancang table grid yang berisi dimensi, deskripsi, dan ilustrasi. Dimensi kecerdasan moral ditentukan berdasarkan referensi yang diperoleh dari buku dan artikel. Berdasarkan referensi yang telah dikumpulkan, peneliti memilih 7 aspek kecerdasan moral terdapat 14 item ilustrasi dengan 3 pertanyaan. 2) Item pertanyaan ditulis untuk menentukan tanggapan anak terhadap ilustrasi yang disajikan. Pertanyaan yang terstruktur terkait dengan apa yang dipikirkan, dirasakan, dan dilakukan anak; 3) Instrumen yang telah tersusun diberikan kepada dua ahli (doktor dan praktisi pendidikan) untuk mengetahui kesesuaian item, saran, dan modifikasi item pada instrumen; (4) Selanjutnya dilakukan pengumpulan data untuk mengetahui respon anak terhadap ilustrasi pada buklet; (5) Respon anak dikategorikan dalam rentang 1-3 (rendah-tinggi); (6) Setelah dilakukan kategorisasi terhadap respon anak, selanjutnya peneliti melakukan analisis untuk mengetahui validitas dan reliabilitasn skala kecerdasan moral. Langkah-langkah penyusunan instrumen pada penelitian ini disajikan pada began 1. Adapun kisi-kisi skala kecerdasan moral disajikan pada tabel 1.

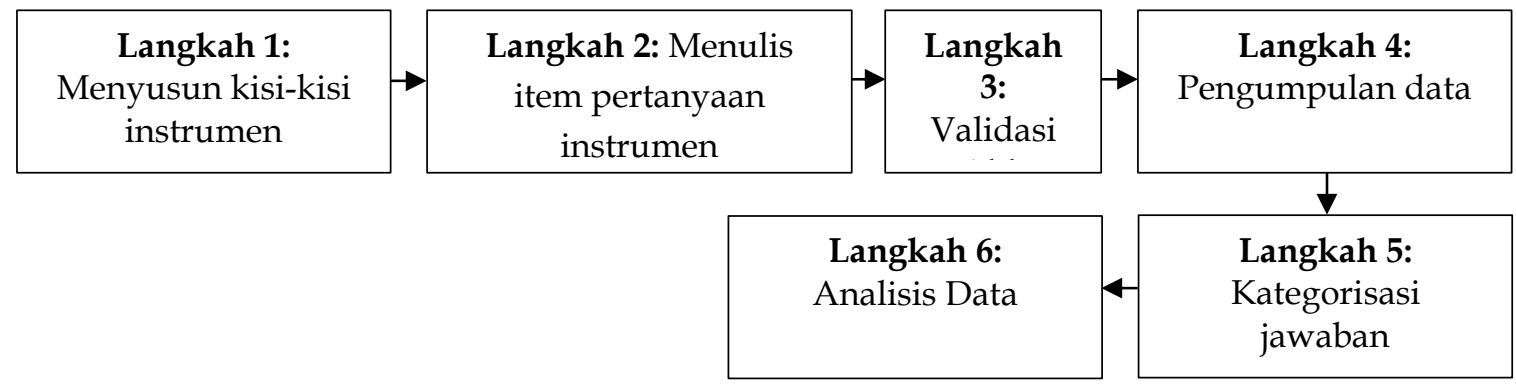

Bagan 1. Langkah-langkah Penyusunan Instrumen Kecerdasan Moral (Khampa, 2019):

Beberapa ahli menyatakan bahwa kecerdasan moral mencakup 3 ranah moral yaitu, pengetahuan moral, perasaan moral, dan perilaku moral. Sesuai dengan pendapat para ahli, terdapat 3 item pertanyaan pada setiap ilustrasi. Tanggapan atas pertanyaan "bagaimana menurut Anda?" merupakan indikator pengetahuan anak-anak tentang nilai kebaikan dalam masyarakat. Tanggapan atas pertanyaan "bagaimana perasaan Anda?" merupakan indikator 
sikap mencintai nilai-nilai kebaikan dalam masyarakat. Adapun jawaban atas pertanyaan "apa yang kamu lakukan?" merupakan indikator kesadaran anak untuk bertindak sesuai dengan nilai-nilai kebaikan di masyarakat. Setiap respon diberi skor 1 poin. Gambar digunakan untuk memudahkan anak memahami ilustrasi yang dibacakan secara lisan, mengingat anak usia dini belum lancar membaca. Skala kecerdasan moral dapat dilihat pada tabel 1.

Tabel 1. Skala Kecerdasan Moral

\begin{tabular}{|c|c|c|c|c|c|}
\hline Variabel & $\begin{array}{c}\text { Sub- } \\
\text { variabel }\end{array}$ & Deskriptor & Indikator & Ilustrasi & $\begin{array}{l}\text { Kriteria } \\
\text { Jawaban }\end{array}$ \\
\hline \multirow[t]{14}{*}{$\begin{array}{l}\text { Kecerdasan } \\
\text { Moral }\end{array}$} & \multirow[t]{2}{*}{ Empati } & \multirow[t]{2}{*}{$\begin{array}{l}\text { Kemampuan untuk } \\
\text { memahami kebutuhan } \\
\text { dan perasaan orang lain }\end{array}$} & $\begin{array}{l}\text { Menunjukkan } \\
\text { kepedulian terhadap } \\
\text { orang lain }\end{array}$ & $\begin{array}{l}\text { Anak melihat teman } \\
\text { jatuh }\end{array}$ & 1 \\
\hline & & & $\begin{array}{l}\text { Memahami } \\
\text { kebutuhan orang lain }\end{array}$ & $\begin{array}{l}\text { Anak melihat seorang } \\
\text { pengemis }\end{array}$ & 2 \\
\hline & \multirow[t]{2}{*}{$\begin{array}{l}\text { Hati } \\
\text { Nurani }\end{array}$} & \multirow{2}{*}{$\begin{array}{l}\text { Kemampuan untuk } \\
\text { memilih perilaku yang } \\
\text { baik dan benar sesuai } \\
\text { dengan aturan daripada } \\
\text { memilih jalan yang } \\
\text { menyimpang, merasa } \\
\text { bersalah ketika } \\
\text { menyimpang dari aturan }\end{array}$} & $\begin{array}{l}\text { Meminta maaf ketika } \\
\text { melakukan } \\
\text { kesalahan }\end{array}$ & $\begin{array}{l}\text { Anak tidak sengaja } \\
\text { mematahkan mainan } \\
\text { teman }\end{array}$ & 3 \\
\hline & & & $\begin{array}{l}\text { Meminta ijin ketika } \\
\text { menginginkan } \\
\text { sesuatu }\end{array}$ & $\begin{array}{l}\text { Anak tertarik dengan } \\
\text { mainan yang dipegang } \\
\text { oleh teman }\end{array}$ & 4 \\
\hline & \multirow[t]{2}{*}{$\begin{array}{l}\text { Kontrol } \\
\text { Diri }\end{array}$} & \multirow[t]{2}{*}{$\begin{array}{l}\text { Kemampuan anak untuk } \\
\text { menahan diri dari } \\
\text { perilaku yang tidak baik }\end{array}$} & $\begin{array}{l}\text { Menahan diri untuk } \\
\text { membuat keributan }\end{array}$ & $\begin{array}{l}\text { Anak sedang } \\
\text { mengikuti kegiatan } \\
\text { mendengarkan cerita } \\
\text { yang dibacakan ibu } \\
\text { guru }\end{array}$ & 5 \\
\hline & & & $\begin{array}{l}\text { Menjaga kebersihan } \\
\text { lingkungan }\end{array}$ & $\begin{array}{l}\text { Anak makan snack } \\
\text { hingga tersisa } \\
\text { bungkusnya }\end{array}$ & 6 \\
\hline & \multirow[t]{2}{*}{$\begin{array}{l}\text { Rasa } \\
\text { hormat }\end{array}$} & \multirow[t]{2}{*}{$\begin{array}{l}\text { Kemampuan anak untuk } \\
\text { menghormati orang lain } \\
\text { seperti menghormati diri } \\
\text { sendiri }\end{array}$} & $\begin{array}{l}\text { Menghormati orang } \\
\text { lain }\end{array}$ & $\begin{array}{l}\text { Ibu guru sedang } \\
\text { berbicara / menasehati } \\
\text { setelah anak membuat } \\
\text { kesalahan }\end{array}$ & 7 \\
\hline & & & $\begin{array}{l}\text { Menghormati diri } \\
\text { sendiri }\end{array}$ & $\begin{array}{l}\text { Anak melakukan } \\
\text { kesalahan saat } \\
\text { membuat hasil karya } \\
\text { (Menggunting tidak } \\
\text { terkontrol) }\end{array}$ & 8 \\
\hline & \multirow[t]{2}{*}{$\begin{array}{l}\text { Kebaikan } \\
\text { Hati }\end{array}$} & \multirow{2}{*}{$\begin{array}{l}\text { Kemampuan anak untuk } \\
\text { bersikap belas kasih } \\
\text { terhadap orang lain }\end{array}$} & $\begin{array}{l}\text { Memahami } \\
\text { kebutuhan orang lain }\end{array}$ & $\begin{array}{l}\text { Anak melihat teman } \\
\text { tidak membawa bekal }\end{array}$ & 9 \\
\hline & & & $\begin{array}{l}\text { Memahami kesulitan } \\
\text { orang lain }\end{array}$ & $\begin{array}{l}\text { Anak melihat teman } \\
\text { kesulitan membawa } \\
\text { banyak buku }\end{array}$ & 10 \\
\hline & \multirow[t]{2}{*}{ Toleransi } & \multirow{2}{*}{$\begin{array}{l}\text { Kemampuan anak untuk } \\
\text { menghargai dan } \\
\text { menghomati orang lain } \\
\text { walaupun memiliki } \\
\text { perbedaan }\end{array}$} & $\begin{array}{l}\text { Tidak membeda- } \\
\text { bedakan teman }\end{array}$ & $\begin{array}{l}\text { Anak melihat teman } \\
\text { yang berbeda fisik } \\
\text { ingin ikut bermain }\end{array}$ & 11 \\
\hline & & & $\begin{array}{l}\text { Mendahulukan } \\
\text { kepentingan teman } \\
\text { yang memiliki } \\
\text { perbedaam }\end{array}$ & $\begin{array}{l}\text { Anak sedang berbaris } \\
\text { mengantri dan melihat } \\
\text { seorang teman yang } \\
\text { menggunakan kursi } \\
\text { roda ikut berbaris } \\
\text { dibelakang anak }\end{array}$ & 12 \\
\hline & \multirow[t]{2}{*}{ Keadilan } & \multirow[t]{2}{*}{$\begin{array}{l}\text { Kemampuan anak untuk } \\
\text { memperlakukan orang } \\
\text { lain dengan cara adil dan } \\
\text { tidak semena-mena }\end{array}$} & $\begin{array}{l}\text { Berlaku adil dengan } \\
\text { semua teman }\end{array}$ & $\begin{array}{l}\text { Anak membawa } 4 \\
\text { mainan, lalu } 2 \text { orang } \\
\text { teman ingin meminjam } \\
\text { mainan yang dibawa } \\
\text { oleh anak }\end{array}$ & 13 \\
\hline & & & $\begin{array}{l}\text { Mengingatkan teman } \\
\text { dengan cara yang } \\
\text { baik }\end{array}$ & $\begin{array}{l}\text { Anak melihat teman } \\
\text { yang bermain tidak } \\
\text { sesuai dengan aturan } \\
\text { (Melempar-lempar } \\
\text { mainan) }\end{array}$ & 14 \\
\hline
\end{tabular}


14 item dan ilustrasi ini disusun ke dalam buklet dengan panduan yang diperlukan. Sebelum penelitian dilakukan, peneliti meminta izin aktif dari anak-anak karena melibatkan partisipasi anak secara langsung, serta persetujuan pasif dari orangtua berupa formulir persetujuan (informed consent) melalui sekolah. Setelah memenuhi kriteria validasi ahli dan mendapat persetujuan dari orang tua, peneliti kemudian membacakan cerita pendek dan menunjukkan gambar pada anak secara pribadi dan secara bergiliran. Peneliti bekerja dalam tim yang terdiri dari 3 orang untuk melakukan storytelling test pada anak-anak. Lokasi penelitian menyesuaikan dengan keinginan anak.

Rata-rata anak membutuhkan waktu sekitar 10-30 menit untuk menjawab pertanyaan peneliti, namun beberapa anak membutuhkan waktu lebih dari 30 menit karena tergantung kesiapan dan kondisi anak. Selanjutnya peneliti mencatat jawaban anak untuk melakukan kategorisasi. Respon anak dikategorikan menjadi 3 tingkatan kriteria jawaban untuk memudahkan peneliti memberi skor. Pengkategorian disesuaikan dengan skala pengukuran yaitu tinggi, sedang, dan rendah.

Pengumpulan data dilakukan dengan (a) validasi ahli yaitu berupa penilaian secara kuantitatif dan secara kualitatif. Adapun validator pada penelitian ini adalah doktor dan praktisi pendidikan; (b) uji coba lapangan menggunakan storytellingtest dengan bantuan buklet gambar. Adapun analisis data yang dilakukan adalah analisis data kuantitatif dengan menguji validitas serta reliabilitas instrumen.

\section{HASIL DAN PEMBAHASAN}

Analisis data pada penelitian ini meliputi analisis validitas dan reliabilitas skala kecerdasan moral. Sebelum dilakukan uji validitas dan reliabilitas instrumen, instrumen diberikan kepada ahli untuk dilakukan validasi. Validasi ahli sangat diperlukan dalam penelitian untuk mengetahui ketepatan (validitas) instrumen ditinjau dari berbagai aspek (Hulukati \& Rahmi, 2020). Hasil validiasi ahli selanjutnya dianalisis untuk mengetahui kriteria kevalidan instrumen, saran, serta modifikasi dari ahli. Analisis datanya adalah sebagai berikut:

\section{Validitas Skala}

Validitas mengungkapkan keakuratan alat ukur dalam mengukur apa yang sedang diukur (Bolarinwa, 2015); (Quansah, 2017). Penilaian validitas skala kecerdasan moral menggunakan pendapat ahli (expert judgement) yaitu guru dan doktor bidang PAUD. Para ahli memberikan saran modifikasi dan evaluasi untuk mengonfirmasi validitas wajah dan validitas konten. Suatu tes memiliki validitas wajah jika isinya relevan dengan responden yang terlibat dalam penelitian. Validitas wajah mengevaluasi skala tampilan yang mencakup kelayakan, konsistensi gaya, format, keterbacaan, dan kejelasan bahasa yang digunakan (Taherdoost, 2018). Sedangkan validitas isi memerlukan penilaian setiap item untuk menentukan relevansinya dengan konstruksi yang dimaksudkan, yaitu untuk memastikan bahwa item skala tersebut mewakili sampel secara keseluruhan (Yassir, McIntyre, \& Bearn, 2017). Proses analisis item bertujuan untuk memastikan validitas setiap item pada skala. Hasil analisis menunjukkan bahwa semua item pada skala kecerdasan moral memiliki validitas isi yang tinggi yaitu untuk ahli 1 sebesar 0,96 dan ahli 2 sebesar 0,86. Perhitungan prediksi validitas menggunakan rumus korelasi product-moment. Data hasil validasi ahli dan saran ahli disajikan pada tabel 4 dan 5 .

Berdasarkan tabel data validasi ahli dan saran ahli, dapat disimpulkan bahwa instrumen kecerdasan moral dapat digunakan untu mengukur kecerdasan moral pada anak usia 5-6 tahun. Setelah dilakukan validasi ahli, selanjutnya peneliti melakukan pengumpulan data kecerdasan moral terhadap 208 anak usia dini di Kota Semarang. Setelah data terkumpul selanjutnya dilakukan analisis untuk mengetahui validitas dan reliabilitas skala kecerdasan moral. 
Tabel 4. Data Validasi Ahli Kecerdasan Moral

\begin{tabular}{|c|c|c|c|c|}
\hline No & Indikator & Uraian & $\begin{array}{c}\text { Skor } \\
\text { Validator 1 } \\
\end{array}$ & $\begin{array}{c}\text { Skor } \\
\text { Validator } 2 \\
\end{array}$ \\
\hline & Ilustrasi & $\begin{array}{l}\text { Kesesuaian ilustrasi gambar dengan indikator } \\
\text { kecerdasan moral. }\end{array}$ & 5 & 5 \\
\hline & & $\begin{array}{l}\text { b. Gambar yang digunakan dapat memberikan ilustrasi } \\
\text { yang sesuai dengan keadaan yang sebenarnya. }\end{array}$ & 5 & 4 \\
\hline & & $\begin{array}{l}\text { c. Gambar yang digunakan dapat mempermudah anak } \\
\text { untuk membayangkan dan memahami pertanyaan } \\
\text { peneliti. }\end{array}$ & 4 & 4 \\
\hline \multirow[t]{2}{*}{2.} & Daya Tarik & Tampilan gambar menarik perhatian anak. & 5 & 5 \\
\hline & $\begin{array}{l}\text { dan } \\
\text { Tampilan } \\
\text { Gambar }\end{array}$ & $\begin{array}{l}\text { b. Gambar yang digunakan disusun dengan baik } \\
\text { sehingga tidak mudah rusak. }\end{array}$ & 5 & 4 \\
\hline 3. & Bahasa & $\begin{array}{l}\text { Menggunakan bahasa yang sesuai dengan kaidah } \\
\text { bahasa Indonesia. }\end{array}$ & 5 & 4 \\
\hline \multicolumn{3}{|c|}{ Total skor } & 29 & 26 \\
\hline \multicolumn{3}{|c|}{ Persentase Validitas } & $96 \%$ & $86,7 \%$ \\
\hline \multicolumn{3}{|c|}{ Kriteria } & $\begin{array}{l}\text { Sangat } \\
\text { Valid }\end{array}$ & $\begin{array}{l}\text { Sangat } \\
\text { Valid }\end{array}$ \\
\hline
\end{tabular}

Tabel 5. Saran Ahli Kecerdasan Moral

\begin{tabular}{cll}
\hline No & Validator & \\
\hline 1. & Ahli 1 & $\begin{array}{l}\text { Instrumen storytelling test ini sangat baik dan dapat digunakan untuk } \\
\text { mengukur kecerdasan moral anak usia dini tanpa revisi. }\end{array}$ \\
2. & Ahli 2 & $\begin{array}{l}\text { Ilustrasi yang telah disusun baik untuk digunakan referensi sumber bacaan/ } \\
\text { storytelling anak. Guru/orangtua dapat menggunakannya untuk media } \\
\text { penanaman moral/ akhlak mulia. Peneliti dapat mengembangkan ilustrasi } \\
\text { menjadi produk yang lebih lengkap dan baik. }\end{array}$ \\
\hline
\end{tabular}

\section{Analisis Item}

Analisis item adalah teknik yang digunakan untuk memeriksa item dalam skala. Teknik analisis ini dilakukan untuk menghilangkan item yang tidak konsisten. Pengujian validitas item pada penelitian ini menggunakan teknik korelasi product moment dan analisis dengan teknik corrected item total correlation. Analisis dengan teknik korelasi product moment dilakukan dengan mengkorelasikan setiap skor pada variabel dengan total skor masingmasing variabel. Hasil perhitungan kemudian dibandingkan dengan nilai kritis pada taraf signifikansi 5\% (0.05). Analisis korelasi dari total item yang diteliti menunjukkan bahwa semua item pada skala berkorelasi dengan skor tes secara keseluruhan (Coskun \& Kara, 2019). Hasil analisis item ditunjukkan pada Tabel 6.

Tabel 6 menunjukkan bahwa semua item pada skala kecerdasan moral berkorelasi dengan skor tes secara keseluruhan dengan nilai Sig. $<0.05$. Selanjutnya analisis dengan teknik corrected item total correlation. Pada teknik ini, untuk menentukan valid dan tidaknya instrumen peneliti perlu membandingkan antara nilai $r$ hitung dengan $r$ tabel. Apabila nilai $r$ hitung $>r$ tabel dengan taraf signifikansi 5\% maka item pada instrumen dinyatakan valid. Sedangkan, apabila nilai $\mathrm{r}$ hitung $<\mathrm{r}$ tabel maka item pada instrumen dinyatakan tidak valid. Hasil perhitungan menggunakan teknik corrected item total correlation pada penelitian ini menunjukkan bahwa seluruh item pada instrumen memiliki nilai $\mathrm{r}$ hitung $>\mathrm{r}$ tabel (0.138). Adapun hasil perhitungan dapat dilihat pada tabel 7.

Berdasarkan hasil perhitungan menggunakan teknik korelasi product moment maupun dengan teknik corrected item total correlation, dapat disimpulkan bahwa seluruh item pada 
instrumen kecerdasan moral dinyatakan valid. Oleh karena itu, semua item dalam skala kecerdasan moral dapat digunakan untuk mengukur kecerdasan moral anak usia dini.

Tabel 6. Hasil Analisis Item dengan Korelasi Product Moment

\begin{tabular}{|c|c|c|c|}
\hline & & Total & Kriteria \\
\hline \multirow{3}{*}{ Item 1} & Pearson Correlation & .634 & Valid \\
\hline & Sig. (2-tailed) & .000 & \\
\hline & $\mathrm{N}$ & 208 & \\
\hline \multirow[t]{3}{*}{ Item 2} & Pearson Correlation & .625 & Valid \\
\hline & Sig. (2-tailed) & .000 & \\
\hline & $\mathrm{N}$ & 208 & \\
\hline \multirow[t]{3}{*}{ Item 3} & Pearson Correlation & .691 & Valid \\
\hline & Sig. (2-tailed) & .000 & \\
\hline & $\mathrm{N}$ & 208 & \\
\hline \multirow[t]{3}{*}{ Item 4} & Pearson Correlation & .631 & Valid \\
\hline & Sig. (2-tailed) & .000 & \\
\hline & $\mathrm{N}$ & 208 & \\
\hline \multirow[t]{3}{*}{ Item 5} & Pearson Correlation & .551 & Valid \\
\hline & Sig. (2-tailed) & .000 & \\
\hline & $\mathrm{N}$ & 208 & \\
\hline \multirow[t]{3}{*}{ Item 6} & Pearson Correlation & .600 & Valid \\
\hline & Sig. (2-tailed) & .000 & \\
\hline & $\mathrm{N}$ & 208 & \\
\hline \multirow[t]{3}{*}{ Item 7} & Pearson Correlation & .585 & Valid \\
\hline & Sig. (2-tailed) & .000 & \\
\hline & $\mathrm{N}$ & 208 & \\
\hline \multirow[t]{3}{*}{ Item 8} & Pearson Correlation & .698 & Valid \\
\hline & Sig. (2-tailed) & .000 & \\
\hline & $\mathrm{N}$ & 208 & \\
\hline \multirow[t]{3}{*}{ Item 9} & Pearson Correlation & .641 & Valid \\
\hline & Sig. (2-tailed) & .000 & \\
\hline & $\mathrm{N}$ & 208 & \\
\hline \multirow[t]{3}{*}{ Item 10} & Pearson Correlation & .602 & Valid \\
\hline & Sig. (2-tailed) & .000 & \\
\hline & $\mathrm{N}$ & 208 & \\
\hline \multirow[t]{3}{*}{ Item 11} & Pearson Correlation & .626 & Valid \\
\hline & Sig. (2-tailed) & .000 & \\
\hline & $\mathrm{N}$ & 208 & \\
\hline \multirow[t]{3}{*}{ Item 12} & Pearson Correlation & .680 & Valid \\
\hline & Sig. (2-tailed) & .000 & \\
\hline & $\mathrm{N}$ & 208 & \\
\hline \multirow[t]{3}{*}{ Item 13} & Pearson Correlation & .731 & Valid \\
\hline & Sig. (2-tailed) & .000 & \\
\hline & $\mathrm{N}$ & 208 & \\
\hline \multirow[t]{3}{*}{ Item 14} & Pearson Correlation & .614 & Valid \\
\hline & Sig. (2-tailed) & .000 & \\
\hline & $\mathrm{N}$ & 208 & \\
\hline
\end{tabular}


Tabel 7. Hasil Analisis Item dengan Teknik Corrected Item Total Correlation

\begin{tabular}{cccc}
\hline No Item & $\mathrm{r}_{\text {hitung }}$ & $\mathrm{r}_{\text {tabel }} 5 \%(206)$ & Kriteria \\
\hline 1 & .602 & .138 & Valid \\
2 & .588 & .138 & Valid \\
3 & .659 & .138 & Valid \\
4 & .592 & .138 & Valid \\
5 & .508 & .138 & Valid \\
6 & .566 & .138 & Valid \\
7 & .550 & .138 & Valid \\
8 & .667 & .138 & Valid \\
9 & .608 & .138 & Valid \\
10 & .564 & .138 & Valid \\
11 & .591 & .138 & Valid \\
12 & .648 & .138 & Valid \\
13 & .701 & .138 & Valid \\
14 & .580 & .138 & Valid \\
\hline
\end{tabular}

\section{Reliabilitas Skala}

Reliabilitas instrumen harus dihitung sebelum skala digunakan untuk mengukurnya. Skala dapat dinyatakan reliabel jika memberikan hasil yang sama ketika diterapkan pada sampel yang sama secara konsisten (Wadkar, Singh, Chakravarty, \& Argade, 2016). Reliabilitas skala kecerdasan moral anak usia dini ditentukan dengan menghitung koefisien reliabilitas pada sampel 208 anak usia 5-6 tahun di Kota Semarang. Estimasi reliabilitas pada skala likert diukur dengan menggunakan nilai alpha Cronbach (Quansah, 2017). Berdasarkan hasil perhitungan diperoleh nilai Cronbach alpha skala kecerdasan moral dalam penelitian ini adalah 0,75. Nilai tersebut menunjukkan bahwa Skala Kecerdasan Moral memiliki reliabilitas yang baik. Hal ini sesuai dengan (Khumaedi, 2012) yang menyatakan bahwa suatu instrumen dikatakan reliabel apabila besarnya koefisien reliabilitas berkisar antara 0 sampai 1 . Semakin tinggi angka reliabilitasnya maka hasil pengukurannya akan semakin konsisten. Nilai reliabilitas dalam penelitian ini menunjukkan bahwa hasil pengukuran reliabilitas skala kecerdasan moral dapat dipercaya. Namun, skala yang telah terstandarisasi dan dapat diandalkan, perlu dicoba ulang setiap kali digunakan (Tavakol \& Dennick, 2011). Skala yang diuji berulang kali akan meningkatkan kualitas skala, nilai validitas, dan reliabilitas (Hayati \& Lailatussaadah, 2016). Hasil analisis reliabilitas dapat dilihat pada tabel 8.

Tabel 8. Hasil Analisis Reliabilitas

\begin{tabular}{ccccc}
\hline Instrumen & $\mathrm{r}_{\text {hitung }}$ & $\mathrm{r}_{\text {tabel }} 5 \%$ & $\mathrm{~N}$ & Kategori \\
\hline Kecerdasan Moral & .758 & .553 & 15 & Reliabel \\
\hline
\end{tabular}

Hasil penelitian telah menunjukkan bahwa instrumen kecerdasan moral ini layak untuk digunakan untuk mengukur kecerdasan moral anak usia dini. Berbeda dengan pencelitian sebelumnya yang hanya mengukur kecerdasan moral secara umum, pada penelitian ini kecerdasan moral diukur berdasarkan tiga domain moral yaitu pengetahuan, perasaan, dan perilaku moral serta melibatkan anak secara langsung.

Instrumen kecerdasan moral ini telah melalui uji validasi ahli untuk mengetahui ketepatan instrumen ditinjau dari berbagai aspek melalui saran dan modifikasi dari ahli. Adapun ahli yang melakukan penilaian terhadap instrumen kecerdasan moral ini adalah doktor di bidang pendidikan dan praktisi pendidikan. Setelah melalui validasi ahli peneliti meminta izin aktif dari anak-anak karena melibatkan partisipasi anak secara langsung, serta persetujuan pasif dari orangtua/wali mereka (Mahon, Glendinning, Clarke, \& Craig, 1996). Penelitian ini melibatkan anak secara langsung mengingat anak-anak dapat memberikan informasi yang akurat dan berharga (O'Reilly \& Dogra, 2018). Selain itu penelitian 
sebelumnya yang dilakukan oleh (Murray, 2016) menunjukkan bahwa anak-anak dapat mengambil keputusan berdasarkan bukti dalam suatu penelitian yang layak mendapat pengakuan dari pembuat kebijakan.

Penggunaan informed consent dalam penelitian ini dimaksudkan untuk memberikan informasi pada anak bahwa ketika mereka menyetujui untuk ikut serta dalam penelitian, bukan berarti mereka harus ikut sampai akhir pelaksanaan penelitian. Mereka dapat mengundurkan diri kapan saja sesuai dengan keinginan anak (Laws \& Mann, 2004). Hal tersebut juga didukung oleh yang menyatakan bahwa ketika melakukan penelitian pada ana usia dini, peneliti dapat mengidentifikasi apapun yang disukai dan tidak disukai oleh anak (Cree, Kay, \& Tisdall, 2002). Setiap anak akan menunjukkan responnya dengan cara yang berbeda, seperti menangis atau menolak terlibat dengan peneliti maupun alat yang digunakan oleh peneliti.

Setelah mendapatkan izin aktif dari anak-anak dan izin pasif dari orangtua, peneliti melakukan pengumpulan data dengan instrumen yang telah dikembangkan. Adapun teknik pengumpulan data dalam penelitian ini menggunakan storytelling test. Menurut Storytelling merupakan teknik psikologis untuk diagnosis serta intervensi terapeutik. Data yang terkumpul dianalisis untuk diketahui validitas dan reliabilitasnya. Uji validitas item yang juga disebut dengan indeks diskriminasi item dilakukan untuk mengetahui kemampuan item dalam membedakan individu (Winurini, 2016). Validitas suatu instrumen harus selalu diuji karena nilai validitas instrumen dapat dipengaruhi oleh subjek yang diukur, pengguna instrumen, dan instrumen itu sendiri (Yusup, 2018). Berdasarkan pada penjelasan mengenai validitas maka instrumen kecerdasan moral yang telah dikembangkan dapat dipertanggungjawabkan dan digunakan untuk mengukur kecerdasan moral anak usia dini.

Instrumen kecerdasan moral yang dikembangkan ini berupa buklet yang berisi gambar ilustrasi, cerita singkat, dan pertanyaan yang meliputi tiga domain moral (pikirkan, rasakan, lakukan). Instrumen ini juga dilengkapi dengan buku pedoman penggunaan instrumen yang dilengkapi dengan kisi-kisi instrumen, pedoman penggunaan dan pedoman penskoran instrumen. Penggunaan buklet dengan gambar dalam penelitian ini digunakan mengingat responden dalam penelitian adalah anak-anak, sehingga anak-anak dapat berpartisipasi secara langsung dalam kegiatan penelitian. Anak-anak (termasuk anak kecil) diterima sebagai informan yang dapat dipercaya tentang kehidupan mereka sendiri (Leonard, 2020). Peneliti menggunakan teknik stortellingtest untuk membacakan cerita singkat pada anak dan melihat respon anak terhadap ilustrasi. Storytelling memiliki tradisi panjang sebagai teknik psikologis untuk diagnosis serta untuk intervensi terapeutik (Mills \& Crowley, 2014); (Vane, J. R. (1981).

Meskipun penelitian dalam bidang penceritaan cerita diagnostik dan terapeutik memerlukan pengembangan lebih lanjut, studi validitas dan reliabilitas yang dilaporkan di sini menawarkan bukti bahwa storytellingtest dapat memberi dokter dan peneliti alat diagnostik yang berpotensi layak yang dirancang khusus untuk digunakan untuk anak-anak yang menunjukkan kesulitan perilaku dan emosional. Penelitian tentang penggunaan teknik aperseptif mendukung popularitas sebagai diagnostic dan alat wawancara di sekolah dan pengaturan klinis (Brown \& McGuire, 1976); (Goh, Teslow, \& Fuller, 1981). Kuesioner telah digunakan pada penelitian yang melibatkan anak-anak dan remaja dengan menggunakan child-frendly. Contohnya studi The British Household Panel di Inggris menggunakan kuesioner yang child-friendly yaitu berupa rekaman dimana pertanyaan dimainkan melalui stereo pribadi dan dijawab oleh anak-anak dalam buklet mereka sendiri dalam waktu tertentu (Scott, 2008). Peneliti lain telah menggunakan kuesioner yang meminta anak-anak untuk memilih gambar wajah anak yang menunjukkan bagaimana perasaan mereka terhadap aktivitas tertentu (Clark, 2005). 


\section{SIMPULAN}

Instrumen kecerdasan moral yang melibatkan partisipasi anak secara langsung untuk mengukur apa yang anak pikirkan, rasakan, dan lakukan telah tersusun dan melewati proses validasi ahli. Hasil analisis menunjukkan bahwa seluruh item pada instrumen kecerdasan moral dinyatakan valid dan reliabel. Berdasarkan hasil tersebut maka dapat disimpulkan bahwa instrumen kecerdasan moral dapat digunakan untuk mengukur kecerdasan moral pada anak usia dini dengan melibatkan partisipasi anak secara langsung. Oleh karena itu, dalam mengukur kecerdasan moral anak usia dini, penggunaan instrumen kecerdasan moral ini disarankan karena tidak hanya mengukur satu domain moral saja, namun mengukur ketiga domain moral baik pengetahuan, perasaan, maupun perilaku moral.

\section{UCAPAN TERIMA KASIH}

Penelitian ini didanai oleh Direktorat Riset dan Pengabdian Masyarakat Kemenristekdikti pada tahun 2020. Terima kasih kepada semua anak, orang tua, pengasuh, dan guru di Kota Semarang yang mendukung dalam penelitian ini, atas kesediaannya untuk berpartisipasi dalam penelitian ini dan informasi yang diberikan.

\section{DAFTAR PUSTAKA}

Ahsan, Dian, S., Adisantika, \& Ayu, R. A. (2014). Hubungan antara Pola Asuh Orang tua (Ibu) yang Bekerja dengan Tingkat Kecerdasan Moral Anak Usia Prasekolah (4-5) Tahun di TK Mutiara Indonesia Kedungkandang Malang. Journal of Educational Innovation, 2(2), 30-40. https:// doi.org/10.18551/erudio.2-2.5

Ahyani, L. N., \& Dhini, R. D. (2011). Metode Sosiodrama dalam Meningkatkan Kecerdasan Moral Anak. Jurnal Sosial Dan Budaya, 4(2), 143-149. Retrieved from https://media.neliti.com/media/publications/23196-EN-metode-sosiodrama-dalammeningkatkan-kecerdasan-moral-anak.pdf

Al-Somadi, M. M. F. (2012). The Effect of a Story - Based Programme on Developing Moral Values At the Kindergarten Stage. Interdiciplinary Journal of Contemporary Research in Buisiness, 4(7), 534-559. Retrieved from https://journal-archieves25.webs.com/534559.pdf

Altan, M. Z. (2017). Moral Intelligence for More Diverse and Democratic World. European Journal of Education Studies, 3(3), 252-270. https:/ / doi.org/10.5281/zenodo.290617

Auliya, F., Pranoto, Y. K. S., Sunawan, \& Sunarso, A. (2021). The permissive non-parental childcare and moral intelligence: Indonesian setting. International Journal of Evaluation and Research in Education, 10(2), 569-575. https:// doi.org/10.11591/ijere.v10i2.21032

Bolarinwa, O. (2015). Principles and methods of validity and reliability testing of questionnaires used in social and health science researches. Nigerian Postgraduate Medical Journal, 22(4), 195. https:/ / doi.org/10.4103/1117-1936.173959

Borba, M. (2001). Building moral intelligence. San Fransisco: Josey-Bass.

Bozaci, I. (2014). Moral Intelligence and Sustainable Consumption: A Field Research on Young Consumers. International Journal of Academic Research in Business and Social Sciences, 4(11), 306-319. https:// doi.org/10.6007/IJARBSS/v4-i11/1313

Brown, W. R., \& McGuire, J. M. (1976). Current psychological assessment practices. Professional Psychology: Research and Practice, 7(4), 475-484. https:// doi.org/10.1037/0735-7028.7.4.475

Clark, A. (2005). Listening to and involving young children: A review of research and practice. Early Child Development and Care, 175(6), 489-505. https:// doi.org/10.1080/03004430500131288

Coles, R. (2005). The Moral Intelligence of Children. Family Court Review, 36(1), 90-95. https://doi.org/10.1111/j.174-1617.1998.tb00496.x 
Coskun, K., \& Kara, C. (2019). Moral identity test (MIT) for children: reliability and validity. Psicologia: Reflexao e Critica, 32(1). https:// doi.org/10.1186/s41155-019-0120-9

Cree, V. E., Kay, H., \& Tisdall, K. (2002). Research with children: Sharing the dilemmas. Child and Family Social Work, 7(1), 47-56. https:// doi.org/10.1046/j.1365-2206.2002.00223.x

Goh, D. S., Teslow, J., \& Fuller, G. B. (1981). The practice of psychological assessment among school psychologists. Professional Psychology: Research and Practice, 12(6), 696-706. https:// doi.org/10.1037/0735-7028.12.6.696

Hayati, S., \& Lailatussaadah, L. (2016). Validitas Dan Reliabilitas Instrumen Pengetahuan Pembelajaran Aktif, Kreatif Dan Menyenangkan (Pakem) Menggunakan Model Rasch. Jurnal Ilmiah Didaktika, 16(2), 169. https:// doi.org/10.22373/jid.v16i2.593

Hudi, I. (2017). Pengaruh pengetahuan moral terhadap perilaku moral pada siswa smp negeri kota Pekan baru berdasarkan pendidikan orang tua. Jurnal Moral Kemasyarakatan, 2(1), 30-44. Retrieved from http:// ejournal.unikama.ac.id/index.php/JMK

Hulukati, W., \& Rahmi, M. (2020). Instrumen Evaluasi Karakter Mahasiswa Program Pendidikan Guru Pendidikan Anak Usia Dini. Jurnal Obsesi : Jurnal Pendidikan Anak Usia Dini, 4(2), 851. https://doi.org/10.31004/obsesi.v4i2.468

Ibrahim, K. A., \& Al-mehsin, S. A. (2016). The level of moral intelligence among students of Egyptian and Saudi Universities ( Cross-cultural study ). Global Science Research Journals, 4(6), 495-503. Retrieved from https://www.globalscienceresearchjournals.org/

Khampa, D. (2019). Development and standardization of moral intelligence scale. The International Journal of Indian Psychology, 7(4), 657-665. https:// doi.org/10.25215/0704.074

Khumaedi, M. (2012). Reliabilitas Instrumen Penelitian Pendidikan. Jurnal Pendidikan Teknik Mesin, 12(1), 25-30. Retrieved from https://journal.unnes.ac.id/nju/index.php/JPTM/article/view/5273

Kosasih, M., \& Rahmaniah, F. (2014). Perilaku Moral Anak Usia 4-5 Tahun Di Taman KanakKanak. Jurnal Integrasi Sistem Industri, 1(1), 1-8. https:// doi.org/10.24853/jisi.1.1.

Laws, S., \& Mann, G. (2004). So you want to involve children in research? A toolkit supporting children's meaningful participation in research relating to violence against children. Retrieved from papers2://publication/uuid/69F7E6C6-02A1-4A15-94A746AC54388E18

Leonard, M. (2020). The Sociology of Children, Childhood and Generation. The Sociology of Children, Childhood and Generation. https://doi.org/10.4135/9781529714494

Mahon, A., Glendinning, C., Clarke, K., \& Craig, G. (1996). Researching children: Methods and ethics. Children and Society, 10(2), 145-154. https://doi.org/10.1111/j.1099_0860.1996.tb00464.x

Mills, J. C., \& Crowley, R. J. (2014). Therapeutic metaphors for children and the child within, second edition. Therapeutic Metaphors for Children and the Child within, Second Edition. https://doi.org/10.4324/9781315886237

Murray, J. (2016). Young children are researchers: Children aged four to eight years engage in important research behaviour when they base decisions on evidence. European Early Childhood Education Research Journal, 24(5), 705-720. https:// doi.org/10.1080/1350293X.2016.1213565

Naqashzadeh, M., \& Sabahizadeh, M. (2016). The Effect of Training Moral Intelligence Components on the Social Interaction of Female Junior High School Students. Academic Journal of Psychological Studies, 5(2), 1-10. https://doi.org/10.20286/ajps$\underline{0502244}$

O'Reilly, M., \& Dogra, N. (2018). Interviewing Children and Young People for Research. Interviewing Children and Young People for Research. https://doi.org/10.4135/9781526419439 
Oktaviana, N. F., \& Wuryandani, W. (2019). Pengembangan media big book untuk meningkatkan perilaku moral pada anak usia 5-6 tahun Big book media development to improve moral behavior in children aged 5-6 years. Jurnal Pendidikan Dan Pemberrdayaan Masyarakat, 6(1), 32-40. Retrieved from https://doi.org/10.21831/jppm.v6i1.23371

Pranoto, Y. K. S. (2017). Kecerdasan Moral Anak Usia Prasekolah. Jurnal Edukasi, 2(1), 1-7. Retrieved from https://journal.unnes.ac.id/nju/index.php/edukasi/article/view/962

Prasetiawan, H., \& Barida, M. (2018). The profile of adolescent' moral intelligence and practical solution to its improvement efforts. SHS Web of Conferences, 00121, 0-4. https://doi.org/10.2991/icei-17.2018.35

Quansah, F. (2017). The Use of Cronbach Alpha Reliability Estimate In Research Among Students In Public Universities In Ghana. African Journal of Teacher Education, 6(1), 55-64. https:// doi.org/10.21083/ajote.v6i1.3970

Rafika, Risma, D., \& Febrialismanto. (2018). the Moral Intelligence To the Self-Regultion of Children in Kindergarten Waldha Al Islamy At Tampan District of Pekanbaru Hubungan Kecerdasan Moral Dengan Self Regulation Anak Di Tk Waldha Al Islamy ( Why ). Jom Fkip, 5, 1-14.

Raihana, P. A., \& Wiwik, W. (2016). Status Ibu dan Pengaruhnya dalam Kecerdasan Moral $\begin{array}{llll}\text { Anak Prasekolah. Jurnal Indigenous, } & \text { 1(2), }\end{array}$ https:// doi.org/10.23917/indigenous.v1i1.2905

Retnowati, G., Salim, R. M. A., \& Saleh, A. Y. (2018). Effectiveness of Picture Story Books Reading to Increase Kindness in Children Aged 5-6 Years. Lingua Cultura, 12(1), 89. https:// doi.org/10.21512/lc.v12i1.2095

Rosyida, N. R., \& Endang, P. S. (2016). Pengaruh Metode Pembiasaan terhadap Perilaku Moral Anak Kelompok B. Jurnal PAUD Teratai, 5(3), 1-5. https://doi.org/https://jurnalmahasiswa.unesa.ac.id/index.php/paudteratai/article/view/15738/14372

Saleh, K. (2018). Moral Intelligence and its Role in Formulating Children Characters. MultiKnowledge Electronic Comprehensive Journal For Education And Science Publications ( MECSJ), (7), 301-313.

Santrock, J. W. (2007). Perkembangan Anak. Jakarta: Erlangga.

Schneider, M. F., \& Perney, J. (1990). Development of the Children's Apperceptive StoryTelling Test. Psychological Assessment, 2(2), 179-185. https://doi.org/10.1037/10403590.2.2.179

Scott, J. (2008). Children as respondents: The challenge for quantitative methods. In Research with Children: Perspectives and Practices: Second Edition (pp. 87-108). https://doi.org/10.4324/9780203964576

Septiani, D., \& Itto, N. N. (2017). Peran Keterlibatan Ayah dalam Pengasuhan Bagi Perkembangan Kecerdasan Moral Anak. Jurnal Psikologi, 13(2), 120-125. https:// doi.org/10.24014/jp.v13i2.4045

Sit, M. (2010). Optimalisasi Kompetensi Moral Anak Usia Dini. Jurnal Pendidikan Dan Kebudayaan, 16(1), 1-12. https:// doi.org/10.24832/jpnk.v16i1.426

Taherdoost, H. (2018). Validity and Reliability of the Research Instrument: How to Test the Validation of a Questionnaire/Survey in a Research. SSRN Electronic Journal, 5(3), 2836. https://doi.org/10.2139/ssrn.3205040

Tavakol, M., \& Dennick, R. (2011). Making sense of Cronbach's alpha. International Journal of Medical Education, 2, 53-55. https://doi.org/10.5116/ijme.4dfb.8dfd

Wadkar, S. K., Singh, K., Chakravarty, R., \& Argade, S. D. (2016). Assessing the Reliability of Attitude Scale by Cronbach's Alpha. Journal of Global Communication, 9(2), 113. https://doi.org/10.5958/0976-2442.2016.00019.7 
Winurini, S. (2016). Telaah Kecerdasan Moral Remaja melalui Moral Competency Inventory (Studi pada Pelajar di Bali) Moral Intelligence Study of Youth Competency Through Moral Inventory. Aspirasi: Jurnal Masalah-Masalah Sosial, 7(2), 187-197. Retrieved from https://jurnal.dpr.go.id/index.php/aspirasi/article/view/1289

Yassir, Y. A., McIntyre, G. T., \& Bearn, D. R. (2017). Three questionnaires to assess the perception of fixed orthodontic therapy before, during and after treatment: validity and reliability. European Journal of Orthodontics, 39(4), 402-410. https://doi.org/10.1093/ejo/cjw076

Yusup, F. (2018). Uji Validitas dan Reliabilitas Instrumen Penelitian Kuantitatif. Jurnal $\begin{array}{llll}\text { Tarbiyah: Jurnal } \quad \text { Ilmiah } & \text { Kependidikan, }\end{array}$ https://doi.org/10.18592/tarbiyah.v7i1.2100

Zhang, Q., \& Zhao, H. (2017). An Analytical Overview of Kohlberg's Theory of Moral Development in College Moral Education in Mainland China. Open Journal of Social Sciences, 05(08), 151-160. https://doi.org/10.4236/jss.2017.58012 